\title{
Microtectonic measurements and interpretation of the Mesozoic formations in the Villány Hills and Görcsöny-Máriakéménd Ridge, Hungary
}

\author{
Attila Petrik \\ Department of Regional Geology \\ Eötvös Lóránd University, Budapest
}

\begin{abstract}
Within the framework of a National Research Fund project, different types of scientific investigations were carried out with the aim of a comprehensive paleogeographic reconstruction of the Tisza structural unit. As part of this project microtectonic measurements in the area of the Villány Hills and Görcsöny-Máriakéménd Ridge were carried out. Several publications have already appeared concerning the structural development of the Mecsek-Villány area (Csontos and Bergerat 1988, 1993; Benkovics 1997; Csontos et al. 2002), but in these the Villány Hills and their surroundings played a secondary role compared to the Mecsek Mountains. The goal of the present study was to establish the limits of the structural phases and determine their relative and absolute ages. An important issue has been to clarify to what degree the suggested events of structural deformation could be integrated into regional geologic processes. The tectonic conditions of the area of interest were studied through description and analysis of structural elements of 12 investigated quarries within it. Calculated stress field data were also analyzed. Seven quarries in the Villány Hills, five in the Görcsöny-Máriakéménd area, the data of over 650 striae, 550 joints, various ductile deformation elements (folds, flexures) as well as stylolites, were recorded. Integrating these structural elements into the regional geologic processes was of significant importance.
\end{abstract}

\section{Introduction and geologic background}

The Tisza Unit (Fig. 1) is an Intra-Carpathian terrane composed of Late Cretaceous north-vergent nappes (Benkovics et al. 1997; Császár 2005). The Mecsek Mountains form a part of the lowest known tectonic unit of the Tisza Unit, while the Villány Hills, together with the Bihor Nappe of the Apuseni Mountains (Romania), are the immediately overlying thrust sheet (Pap 1990; Györfi and Csontos 1994; Bleahu et al. 1996). These nappes are composed of

\section{Address: $\quad$ A. Petrik: H-2800 Tatabánya, Sárbereki Ltp. 320, Hungary} e-mail: petrik.atus@gmail.com

Received: February 4, 2010; accepted: January 3, 2011 


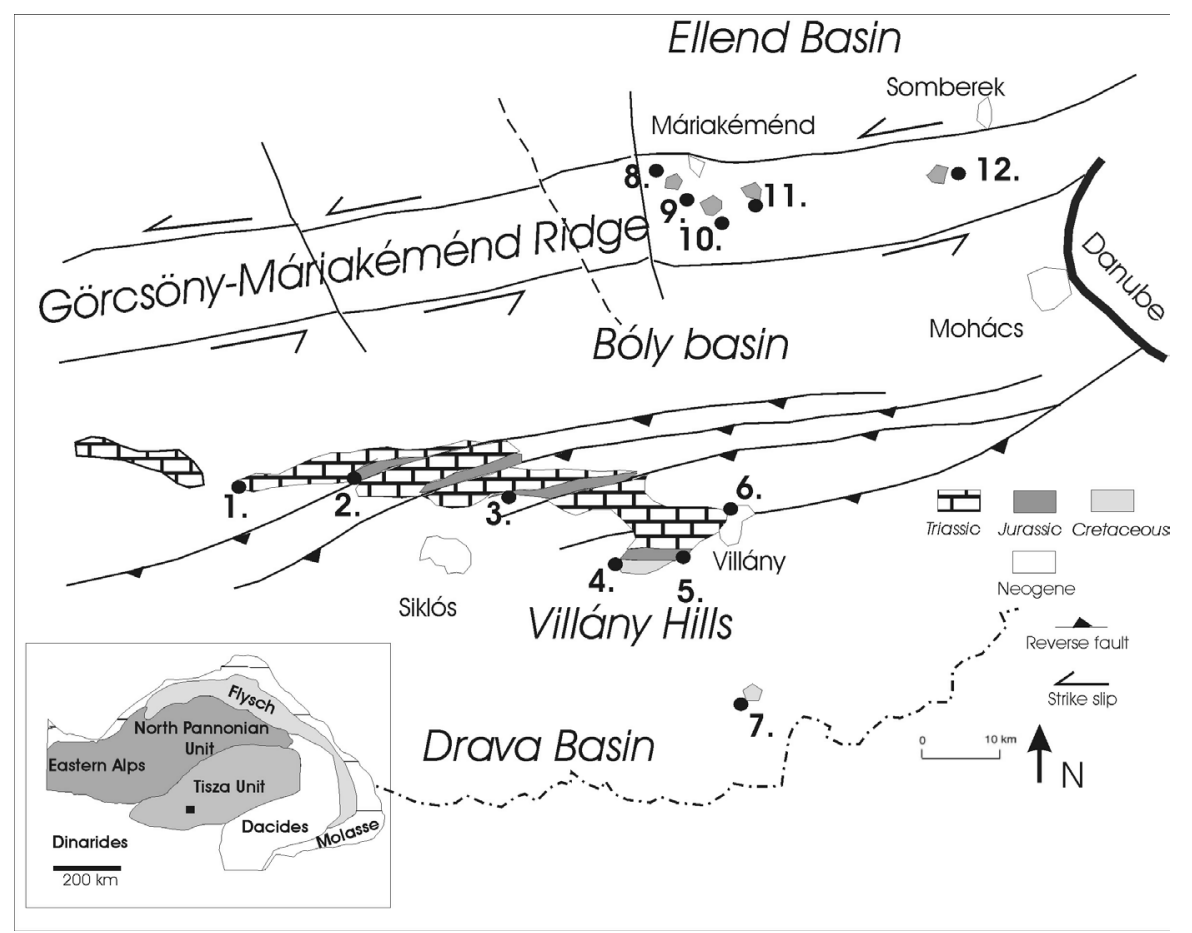

Fig. 1

Map of the studied area showing Mesozoic surface outcrops and major fault lines. The studied quarries were: 1. Csarnóta, 2. Vízügy, 3. Rózsabánya, 4. Harsány Hill, 5. Szobrosbánya, 6. Templom Hill, 7. Beremend, 8. Szederkény I, 9. Szederkény II, 10. Monyoród, 11. Versend, 12. Székelyszabar

crystalline basement and/or granite, Late Paleozoic cover and a Mesozoic sequence (Vadász 1935; Nagy and Nagy 1976; Török 1998). The Villány Hills and the Görcsöny-Máriakéménd Ridge are surface exposures of the Villány-Bihar Zone. The basement of this area is built up by metamorphic crystalline rocks (mica schist, gneiss) and Carboniferous and Permian detrital sedimentary rocks (Fülöp 1994). These lithologies are known only from boreholes. The similarity of the older sequences with the Mecsek ones can be observed through to the Anisian Stage. There is variability regarding the thickness of the formations. The relatively thinner Mesozoic sequence in the Villány Hills is characterized by several gaps and the dominance of the shallow-water deposits (Császár 1992). A carbonate ramp was formed at the beginning of the Triassic, when Germano-type (epicontinental) Triassic rocks were deposited (Török 1998).

The lower part of the Jurassic is condensed and contains many hiatuses. Continuous, thick-bedded limestone sedimentation began in the early Oxfordian (Szársomlyó Limestone Fm.). The Görcsöny-Máriakéménd Ridge is characterized by cherty, crinoidal limestone from the Middle Jurassic. Other Mesozoic 
deposits (Lower Triassic sandstone, Middle Jurassic limestone) are known from boreholes in Somberek. After the Middle Jurassic sedimentation the area between the Mecsek and Villány Hills was probably uplifted. The Upper Jurassic limestone formation was followed by the deposition of bauxite in karstic holes of the Villány Hills. The bauxite is covered by the Lower Cretaceous Urgon-type Nagyharsány Limestone Fm. The Bisse Marl Fm., the age of which is Middle Albian, can also be found on the surface as an erosional remnant. The flysch-type Bóly Sandstone Fm., known only from a borehole, is located in a flexural basin to the north of the Villány Hills (Császár 2002). The beginning of Late Cretaceous nappe formation could have been synchronous with the development of the flexural basin, which had already come into existence in Albian-Cenomanian time (Császár 2002). The construction of the Villány Hills consists of 7 thrust sheets (Fig. 1).

The Villány Hills and the Görcsöny-Máriakéménd Ridge were subjected to erosion until the Middle Miocene. Late Miocene sandstone is typical in different fissures in the Villány Hills. In addition, Pliocene red, clayey silt and Pleistocene loess can be found on the pediments of their surroundings.

\section{Methodology}

The data collection is mainly based on structural measurements. Mesozoic sediments predominate in the Villány Hills. Besides these, there are other sediments in Late Miocene and Pliocene fissure fillings. Seven quarries of Mesozoic sediments were examined, while in the Görcsöny-Máriakéménd Ridge 5 quarries were studied. In the quarries the orientations of the different movement indicators (striae, joints, tensional fissures), ductile deformation elements (folds, duplexes, flexures), and pressolution phenomena (stylolites, slickolites) were recorded. Elements which did not show dislocation - mainly joints and joint systems - were also analyzed. Altogether 650 striae and 550 joints were recorded.

The measurements were compared to those published previously from this area. Paleomagnetic measurements, interpretations of seismic profiles and data of the recent stress fields were also taken into account when determining structural phases. Among data processing software used was Wintensor 1.4.22., developed by Delvaux (Delvaux and Sperner 2003), in order to present stereographic projections of the main stress fields, joints and fold axes. The stress ellipsoid morphology diagrams - which were made from the main stress axis directions and their magnitude ratios - show the tectonic style of the studied area at any given phase.

The Wintensor Program defines the so-called R' values derived from the $\mathrm{R}$ values that represent the stress ratio $(R=\sigma 2-\sigma 3 / \sigma 1-\sigma 3)$. If the tensor field is compressional, $\sigma 3$ will be located vertically and the value of $R$ ' will be $2+R$. If the tensor field is of strike-slip character, $\sigma 2$ will be vertical and R' will be 2-R. If the 
tensor field is tensional, then $\sigma 1$ will be vertical and $\mathrm{R}^{\prime}$ will be equal to $\mathrm{R}$. The value of stress ratio (R) may only be between 0 and 1 , but the value of $R$ ' increases linearly from the radial extensional stress field $\left[R^{\prime}=0\right]$ through to the clearly extensional $\left[R^{\prime}=0.5\right]$, the transtensional $\left[R^{\prime}=1\right]$, the strike-slip $\left[R^{\prime}=1.5\right]$, the transpressional $\left[R^{\prime}=2\right]$, the clearly compressional $\left[R^{\prime}=2.5\right]$, and the radial compressional field $\left[R^{\prime}=3\right]$ (Delvaux 2003). The grouping of the different generations of the striae and joints was carried out using the Phases module of the Tensor 5.45 software, which was developed by Angelier. This module is operated on the Angelier and Mechler (1977) technique, which is a stress inversion method. The different data are connected to their suitable and predefined tensor fields. In some cases, when this happens inappropriately, the grouping is made by cluster analysis or manual method. The tensor calculation is based on comparison and difference of the measured striae and the ideal striae directions calculated by the software. The striae which differed from the ideal values of the stress tensor by more than 20 degrees were weighted as being of lesser importance for the calculation of the stress field.

\section{Results}

In the first part of this section the main stress fields of the study area, created by more than 700 striae and 600 joints, are presented. Beside the presentation of stress fields some structures and models which are typical for a given phase are displayed here as well.

The measured striae were grouped into different populations based on the orientation of main stress axes and the structural conditions of the quarries, such as fault set, fault zone, etc. Altogether 27 local stress fields were calculated (Fig. 6). The stress fields observed in different regions with similar main shortening and extensional directions form 6 regional stress fields (Fig. 6). More than 90\% of the striae could be integrated into these six phases, while those striae showing more than 20 degrees divergence form the main directions were calculated with a lower priority. The separated stress fields belonging to the quarries are also displayed in a table with the main stress directions.

The reconstructed stress field types and their stress ellipsoids showing the main tectonic styles are also demonstrated based on the stress regime diagram developed by Delvaux and Sperner (2003) (Fig. 8). The morphology of the ellipsoids depends on the positions of the main stress directions and their magnitudes ( $R^{\prime}$ value).

\section{Stress field No. 1 (100 striae)}

This stress field is one of the most typical in the study area. It could be observed in almost all quarries in the Villány Hills except Beremend and Templom Hill, but it is also absent from the Görcsöny-Máriakéménd Ridge. The faults belonging to this main phase indicate pure NW-SE compression (Fig. 6). 
The $\sigma 1$ axes are horizontal and their average direction is $334^{\circ}-154^{\circ}$. The stress ellipsoid of this field is located in the compressional region and its $\mathrm{R}^{\prime}$ value is 2.39 emphasizing the importance of shortening deformation (Fig. 8). Most of the striae show a reverse style with NW and SE vergency, but there are some N-S sinistral and NW-SE trending dextral strike-slips. Most of the reverse striae are observable on bedding planes of fold limbs and reverse fault ramps. This stress field is responsible for the high amplitude fold systems (Fig. 2), duplex structures and some backthrusts in the Vízügy and Rózsabánya quarries.

Most of reverse striae can be found on fold limbs with strike perpendicular to the hinges (Fig. 2). The orientations of hinges observed on folded beds lies close to a NE-SW direction, which corresponds perfectly with the compression deduced from reverse faults (Fig. 2).

On the other hand reverse faults of NW-SE direction change continuously into strike-slip ones, according to the morphology demonstrating that their ages are similar and their origins can be related to the first stress field (Fig. 3). According to Maros (1990) and Benkovics (1997) the forces that created the folding have already affected consolidated rocks. They observed reverse striae with NE-SW trends on fold limbs; they did not mention the age of these movements, but correlated them to the formation of folding. Other brittle tectonic indicators such as joints are also assigned to this stress field. They are mostly conjugate fractures with N-S and NE-SW strikes and associated with high amplitude fold systems. Their shapes vary from diagonal to longitudinal ones on fold limbs, creating a systematic joint system which could be coeval with the folding.

Based on relative chronology this stress field is the oldest one because of the striae overprinting. The age of the youngest rocks in which it could be identified is Lower Cretaceous. The vergency of most reverse faults is equal to that of the Villány imbricate system which formed in the Late Cretaceous (Rakusz and Strausz 1953; Nagy and Nagy 1976). Stress analysis suggests that the development of this stress field seems to be of Late Cretaceous age and is responsible for the coeval imbricate formation. This age is also supported by a comparison with the orientation of fold axes (NE-SW) observed in Middle Triassic limestone in the Mecsek Mts (Benkovics et al. 1997); both the direction and supposed ages of formation are similarly Late Cretaceous.

\section{Stress field No. 2 (100 striae)}

This stress field is controlled by several strike-slip faults which mostly display as conjugate faults. The $\sigma 2$ axes are vertical due to the strike-slip tectonic style, while the average direction of $\sigma 3$ is $70^{\circ}-250^{\circ}$ (Fig. 6). The stress ellipsoid of this phase is situated in the strike-slip zone and its $R^{\prime}$ value is 1.45 , indicating the dominance of strike-slips (Fig. 8). This phase indicates NE-SW extension and NW-SE compression owing to the position of stress axes. This stress field can be identified in the Vízügy quarry, in Szobrosbánya and Beremend in the Villány 
Hills as well as in Szederkény and Versend on the Görcsöny-Máriakéménd Ridge. The direction and sense of strike-slips in the latter area are very similar to each other, indicating their common origin (Fig. 6). Most of the strike-slip faults are related to shear zones. Normal faults are typical on bedding planes. The directions of strike-slips vary from N-S, NW-SE to E-W (Fig. 4b). Several normal
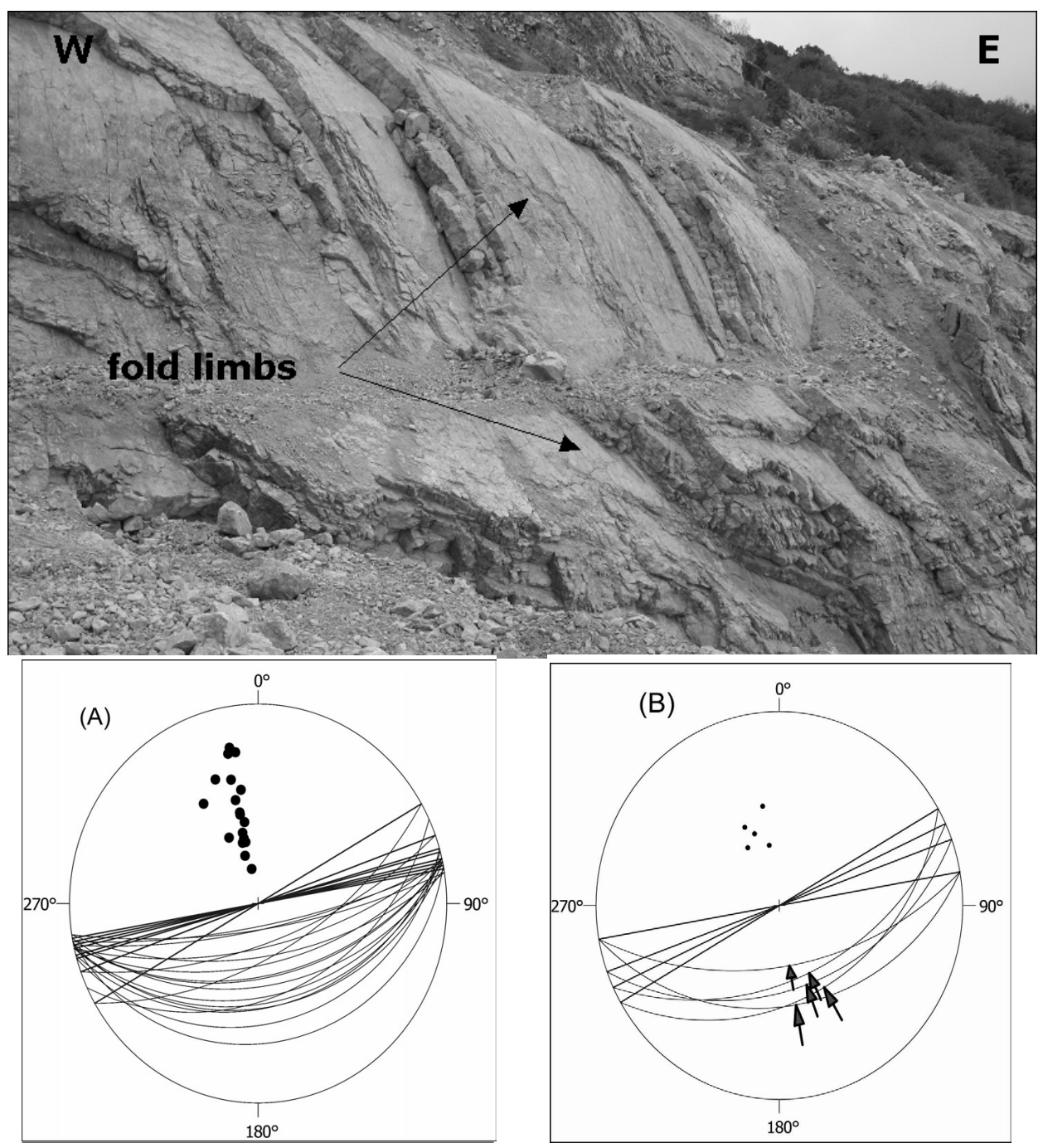

Fig. 2

High-amplitude folds in the Vízügy quarry (near Siklós). The orientation of fold hinges was determined from layers (A) and the reverse striae measured on fold limbs (B). (The stereographic projection was constructed on a Schmidt hemisphere with lower projection.) Legend: Black circles indicate the poles of planes. Straight black lines show the strikes of fold hinges 


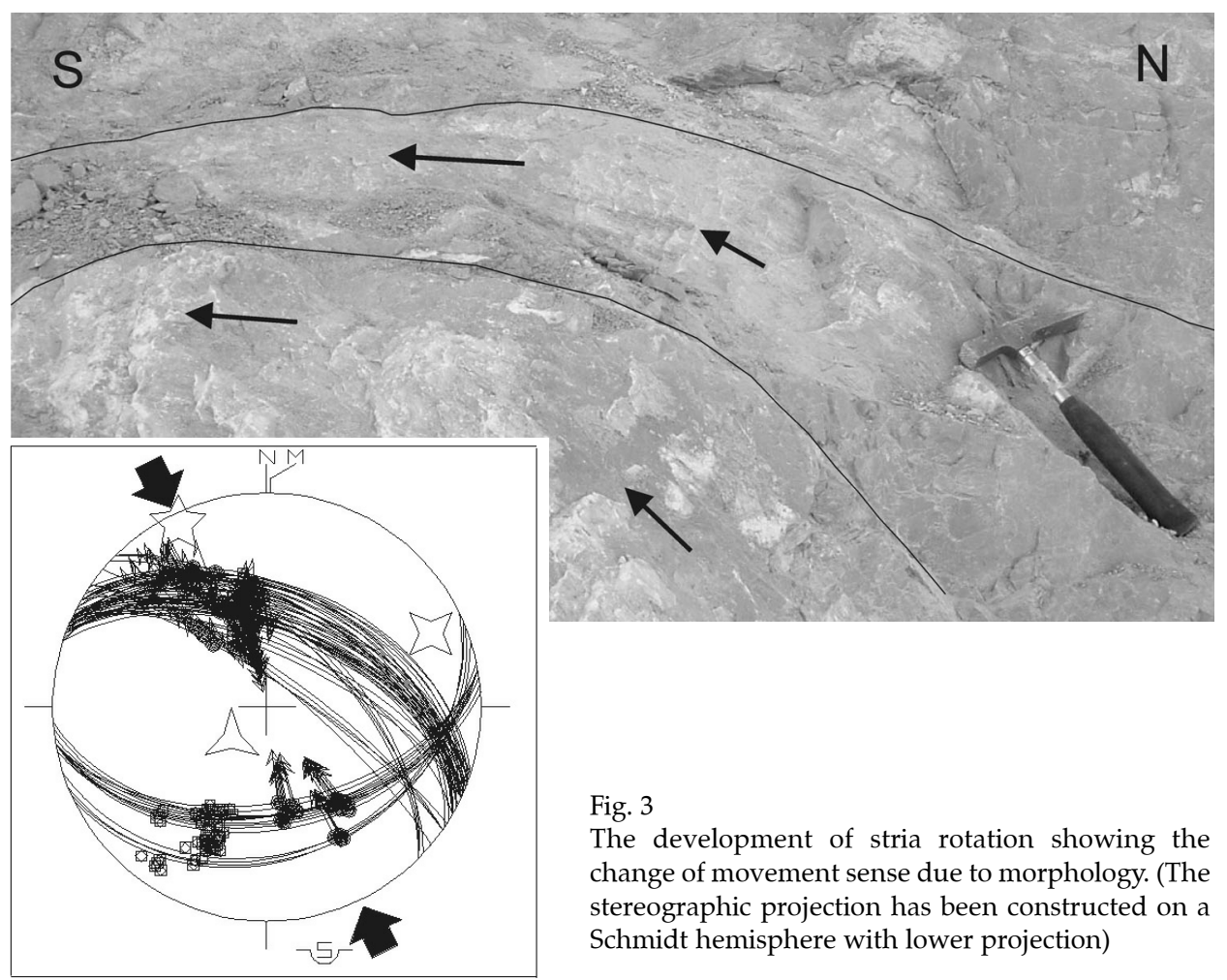

faults with NE-SW direction are also associated with strike-slip faults, especially in Szobrosbánya. On the other hand, in the Szederkény quarries some extension fissures filled with calcite were observed in en-echelon geometry. Their positions indicate the sense of shear in a fault zone (Fig. 4A). Joints matched to this field have a NW-SE strike and are associated with shear zones, which help to determine of the sense of shear.

The youngest rocks which have these striae are of Late Jurassic age. Based on the relative chronology this stress field is younger than the first one confirmed by the crosscutting faults of Szobrosbánya. Reverse faults with NW vergency on bedding planes were crosscut by dextral strike-slip faults found on the subvertical wall, the strike of which is E-W. This deformation phase is probably younger than Late Cretaceous, based on the mentioned crosscutting, but older than Late Miocene, because Late Miocene fissure fillings (Dezsố et al. 2007) and the Pannonian sediments on the Görcsöny-Máriakéménd Ridge do not indicate these movements. The development of this stress field can be put at after Late Cretaceous but before Middle Miocene in accordance with crosscutting faults in Szobrosbánya. This stress field can be related to the elongation of plates, which occurred in the direction of less resistance, in keeping with the beginning of Carpathian subduction. This field created small pull-apart basins of rhomboidal 


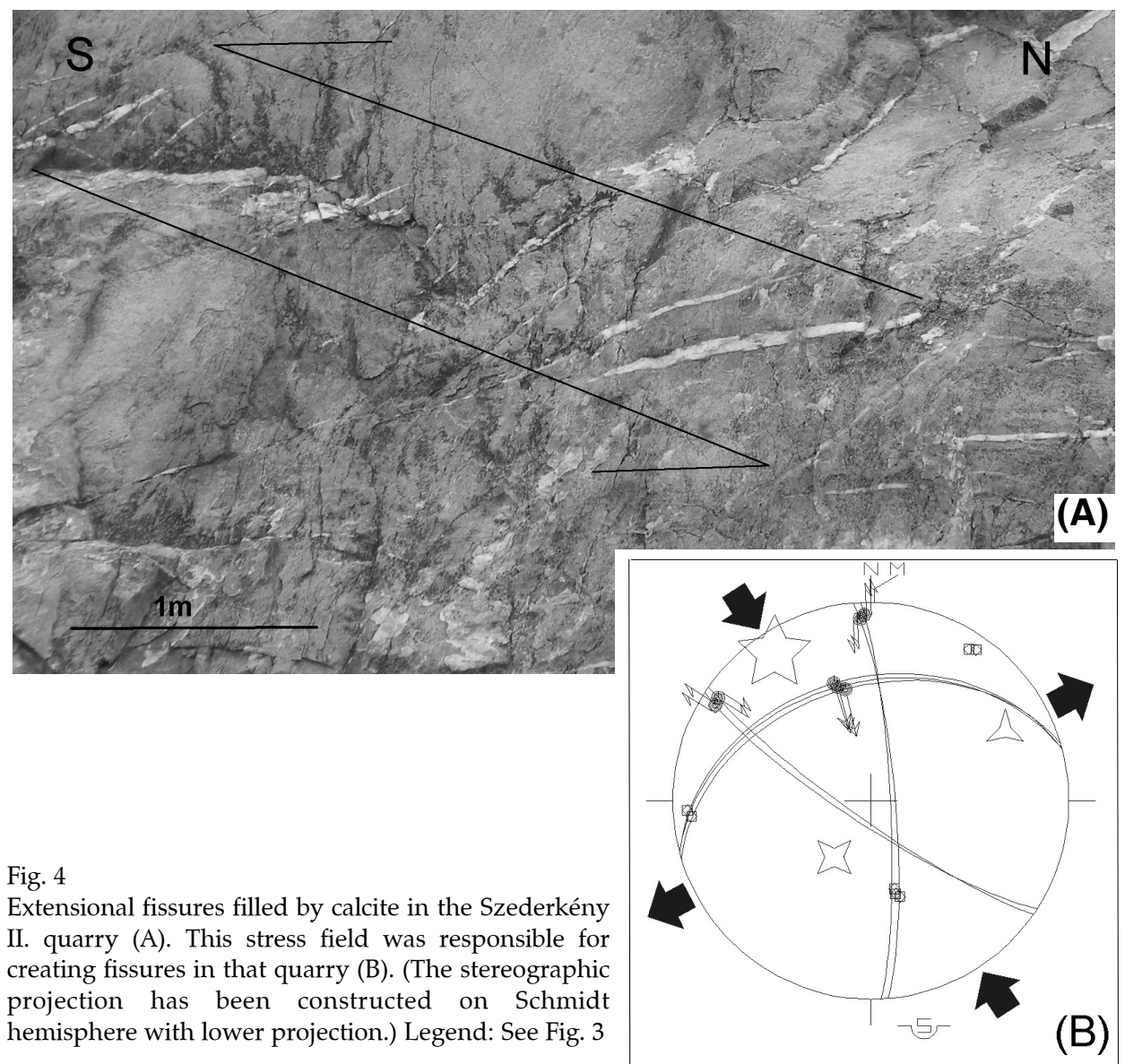

shape, such as the Ellend Basin, between the Mecsek Mts. and the Villany Hills. In this basin the Early and Middle Miocene rocks can be found in greater thickness than in its surroundings; this can indicate the age of the opening basins. The strike of the Drava Basin is perpendicular to the main extensional direction of this phase, but the extensional opening of Nyárád-Harkány Graben and some fissure fillings can also be placed in this period.

\section{Stress field No. 3 (50 striae)}

The third stress field is a N-S tensional one, but in the case of the Beremend quarry it is more of $\mathrm{N}-\mathrm{S}$ transtensional character (Fig. 6). The R' value is almost 1 , indicating the permutation of $\sigma 2$ and $\sigma 1$ stress axes and creating either strikeslips or normal faults. The stress ellipsoid of this field is located in the transtensional region of the tectonic style diagram (Fig. 8). The positions of $\sigma 3$ axes are mostly horizontal and their directions are $\left(175^{\circ}-355^{\circ}\right)$. This stress field 
can be characterized mainly by normal faults, the dip directions of which are unambiguously to the south. Normal faults can be observed on bedding planes, while strike-slip faults can be found in conjugated fault zones. Inverse conjugate fractures were observed in the Beremend quarry where the styles of strike-slip faults are $\mathrm{n}$ contrast to the normal Mohr faults. In this quarry some lenticular and rhomboidal limestone blocks could be observed in connection with shear zones. Their borders are rather sinuous and clay films can be found between them. The development of these bodies could have occurred under brittle conditions and the role of competence contrast was determinant. Several calcite fillings of sigmoid shape were identified between these lenticular bodies, mainly close to the Beremend Cavern. The calcite fillings can be related to different hydrothermal and tectonic activities (Nédli 2004). The tail of the sigmoid shape indicates the sense of shear, which was sinistral with reverse components mostly of southerly direction in these zones (Fig. 5A).

Tensional joint systems of NW-SE and NE-SW strikes are associated with these shear zones and most of them are filled with calcite, due to different hydrothermal activities (Nédli 2004).

Based on the relative chronology this stress field is younger than the second one, which is confirmed by the relationships of normal faults in the Beremend quarry. Those normal faults which belong to the second stress field are crosscut by normal faults, the direction of which is N-S. As the second stress field is of Early Miocene age, the third one should be younger, probably of Middle Miocene age, because the Late Miocene fissure fillings in the Villany Hills and the Pannonian sediments of the Görcsöny-Máriakéménd Ridge were not affected by it. Several basins that evolved in this period are controlled by tensional or transtensional stress fields (Benkovics 1997; Fodor et al. 1999; Csontos et al. 2002). The development of this stress field can be related to block rotation, which began in the Early Miocene. The original direction of the second stress field was approximately $\mathrm{N}-\mathrm{S}$ tension, but due to the $30-40^{\circ}$ clockwise block rotation the original stress field apparently to changed to NE-SW tension. The third stress field with $\mathrm{N}-\mathrm{S}$ tension might have been created after the block rotation. Rotations of substantial angles took place in this region during the Early-Middle Miocene (Márton and Márton 1999; Csontos et al. 2002). The second stress field (NE-SW tensional) changed into a N-S tensional one in the Middle Miocene.

\section{Stress field No. 4. (150 striae)}

This field was identified in almost all quarries of the Villány Hills except Beremend, but was not observed in the quarries of the Görcsöny-Máriakéménd Ridge. This stress field is a transpressional one with $\mathrm{N}-\mathrm{S}$ compression proved by several reverse faults and conjugated strike-slip faults (Fig. 6). Reverse faults could be observed on bedding planes and fold limbs mostly with north and south vergency. Strike-slip faults of NE-SW and NW-SE strike were often associated 


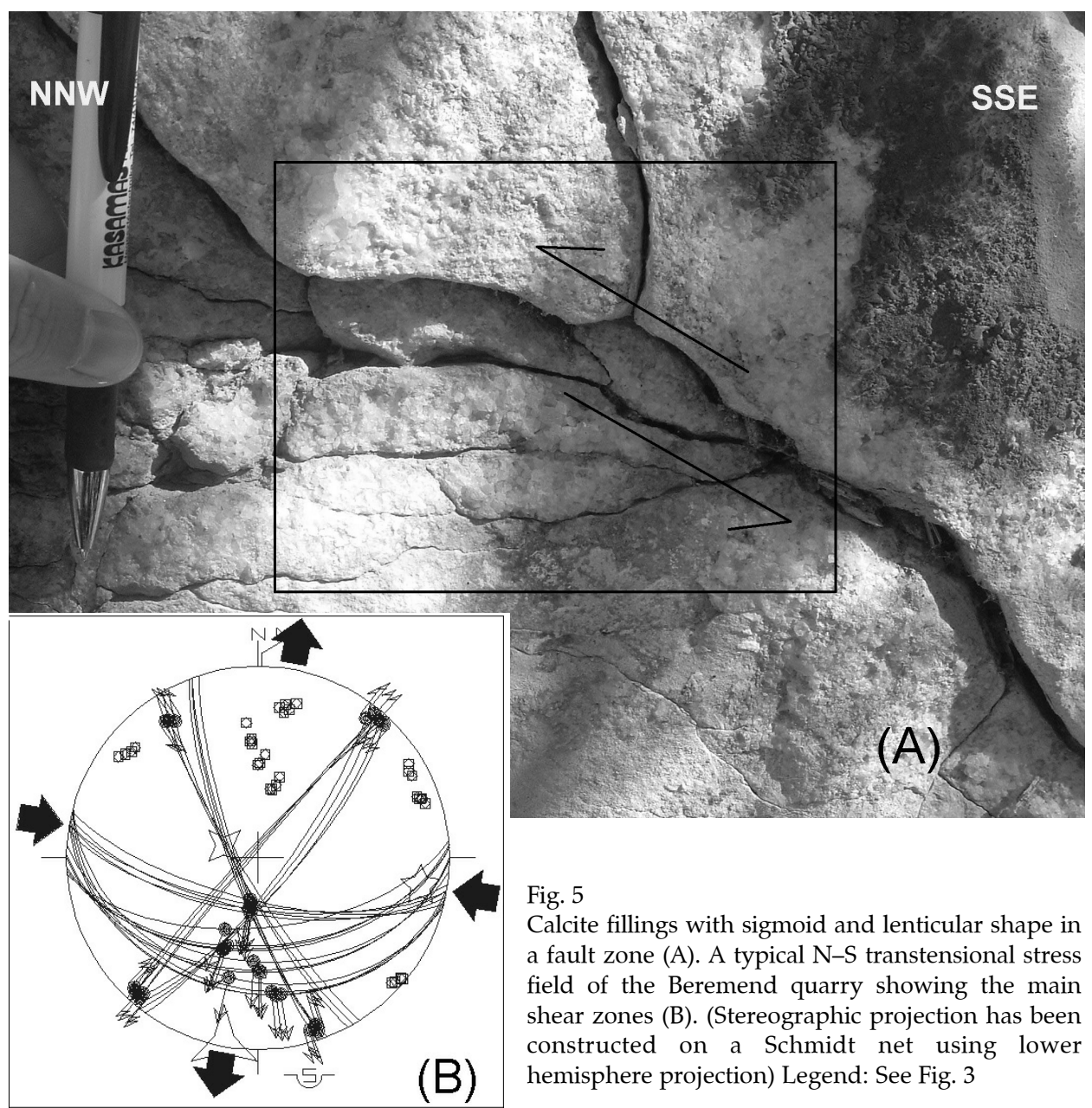

with reverse striae in several fault zones of the Vízügy quarry. The position of maximal stress axis is horizontal and its average direction is $0^{\circ}-180^{\circ}$. The stress ellipsoid of this field is located in the transpressional regime of the diagram, based on R' value (1.94) (Fig. 8).

Several duplexes, back thrusts and folds are related to this stress field. In the Vízügy quarry these structures are situated in a deformation zone of a fissure filling. This infill is made up of Upper Jurassic limestone (Császár 2002); its host rock is also Upper Jurassic limestone, but their colors, materials and stratal dips

Fig. $6 \rightarrow$

Main stress directions, from fault patterns of the studied quarries in the Villány Hills and the Görcsöny-Máriakéménd Ridge. Legend: The numbers in the first row indicate the relative chronology of the stress fields 


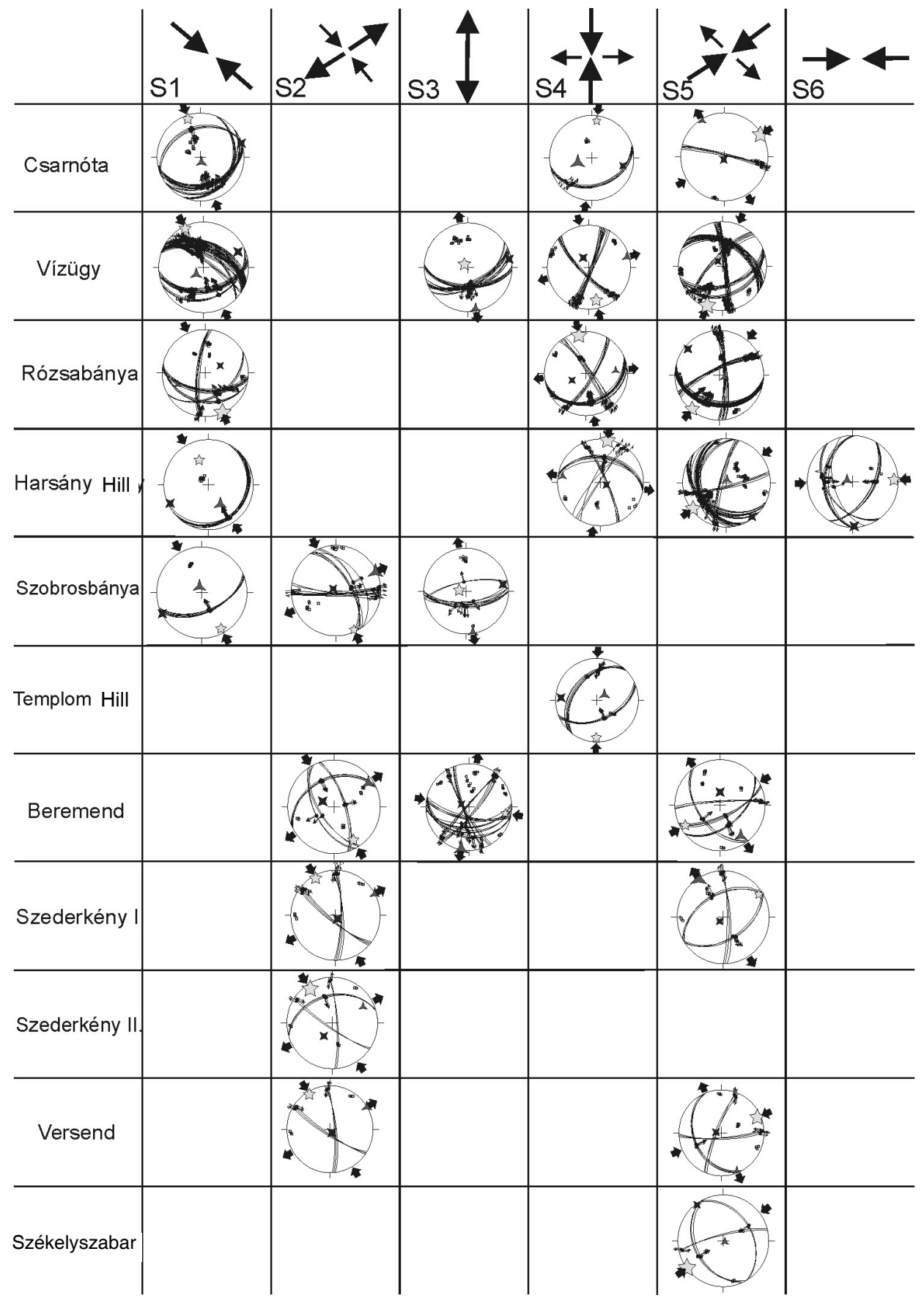


are different. The color of the infill is of a much darker gray than the host rock; its texture is mainly micritic and its stratal dips are lower than that of the host rock (Császár 2002). In addition it exhibits more intense ductile deformation than the host rock. Several reverse faults along bedding planes and north vergent ramp faults, duplexes, folds and back thrusts were observed in this filling (Fig. 7). The hinges of folds and flexures show $\mathrm{E}-\mathrm{W}$ strike. The development of these structures can be explained by bulldozer mechanism, where friction between layers is rather large, detachments cannot be found, and either the entire block moves together above the reverse fault, or smaller slivers are torn off by the thrusted block (Twiss and Moores 1992). As a consequence of this process, the folding and imbricated layers suffered several back thrusts which hampered the creation of further north-vergent reverse faults. A wedge system was developed in connection with backthrusting and some blocks may have been stopped; meanwhile the process underwent clockwise rotation due to space restriction (Fig. 7). Along the bisector plane of conjugated fractures some stylolites were also identified and their directions of peaks correlate very well with the maximal stress axis' (Fig. 7).

This deformation phase was also observed in the Pannonian fissure filling of the Harsány Hill quarry. This fissure filling is made up by mainly clayey sandstone. Reverse striae could be observed in this rock, indicating N-S compression. This infill was examined in terms of petrology and its age was determined to be Late Miocene (Dezső et al. 2007). The relative chronology of this phase was ascertainable due to striae which can be found in this Late Miocene filling. The stress field is interpreted to indicate the beginning of inversion in the study area. Based on several geophysical and microtectonic investigations (Horváth 1993; Fodor et al. 1999; Tari et al. 1999; Bada et al. 2007) the inversion may already have begun in the Late Miocene due to movements of Adriatic Plate. The Late Miocene age (probably Pannonian age) of this stress field is also corroborated by seismic sections and boreholes. For instance, a Triassic limestone block was thrust over Pannonian sediments along the north-verging reverse fault encountered in the Peterd-1 borehole (Nagy and Nagy 1976). The young age of this stress field is also confirmed by folding and flexure of Pannonian sediments and thrusting of the Mesozoic formations on top of the younger Middle and Late Miocene rocks along the Mecsakalja dislocation zone, the GörcsönyMáriakéménd Ridge and the Villány Hills (Wórum 1999). The young compressional forces transformed the pull-apart basins into transpressional ones and produced the reactivation of the former structures.

Based on measurements made as part of this study the GörcsönyMáriakéménd Ridge was not affected by reverse faults belonging to this field. Several reverse faults are displayed on seismic sections along the GörcsönyMáriakéménd Ridge, however, but most of them probably remained blind thrusts. The NW-SE right-lateral strike-slips can be related to the reactivation of the Villány-Szalatnak Fault Zone. According to Némedi Varga (1983) the Villány- 


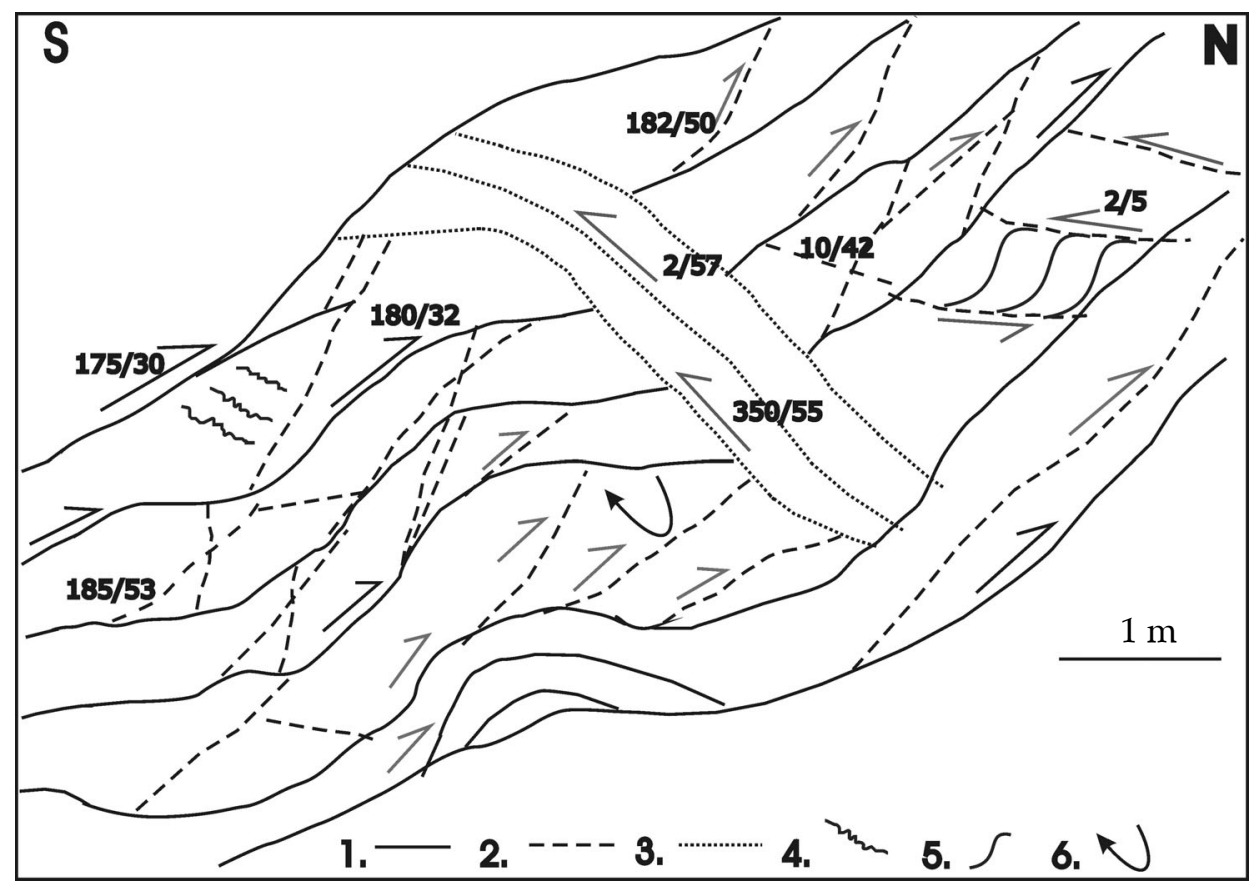

Fig. 7

Detail of chaotically folded N-S wall of the quarry, duplexes, reverse faults along the bedding plane and ramp faults. Legend: 1 . bedding planes, 2 . faults, 3 . back thrusts, 4 . stylolites, 5 . tensional fissures, 6. block rotation

Szalatnak Fault operated like a right-lateral strike-slip fault during the Late Miocene.

\section{Stress field No. 5. (150 striae)}

The most widespread stress field in the studied area is marked by NE-SW transpression. The main shortening direction is NE-SW, while the extensional direction is NW-SE (Fig. 6). The maximal stress axes are horizontal and located in a $\mathrm{N} 60 \mathrm{E}-240^{\circ}$ direction. The stress ellipsoid of this field is located in the transpressional regime in Fig. 8, because the $\mathrm{R}^{\prime}$ value is 2.17 . This stress field is characterized by several reverse faults of NE and SW vergency and conjugated strike-slip faults with N-S and E-W strike. Most of reverse striae were observed on bedding planes as well as ramps; they usually overprinted any other striae. The most typical consequence of this field can be observed in the Harsány Hill quarry. A complex Riedel system was developed in the Lower Cretaceous limestone owing to this stress field. Reverse striae are located along dip directions of bedding planes which are the steepest $\left(180-210^{\circ} / 55-60^{\circ}\right)$ of all the quarries in the Villány Hills. Most of the bedding layers are intersected or linked by Riedel 


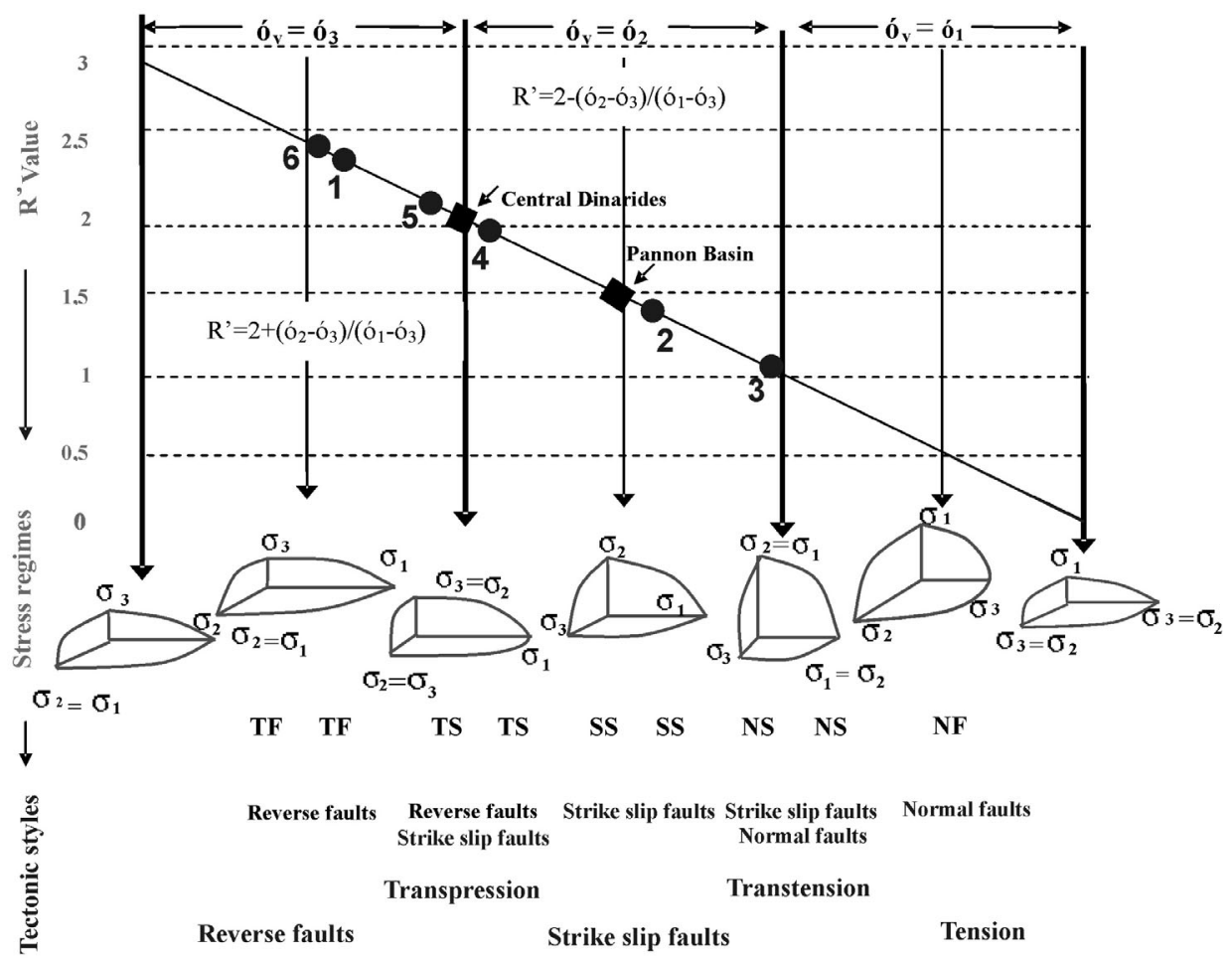

- Stress fields
1. $R^{\prime}=2.39$
4. $R^{\prime}=1.94$
2. $R^{\prime}=1.45$
5. $R^{\prime}=2.17$
3. $R^{\prime}=1.02$
6. $R^{\prime}=2.44$

Fig. 8

Tectonic style of the stress fields and morphology of their stress ellipsoids. Based on Delvaux and Sperner (2003), the diagram was modified by Bada et al. (2007), data after Petrik (2009) and this study. Numbers refer to $R^{\prime}$ values of the corresponding stress fields

faults where the sense of shear is the same as along bedding planes (Fig. 9). Riedel faults are often associated with antithetic Riedel faults, being inclined much more steeply to the layers. Some shear zones could be observed close to the main reverse faults filled by tectonic breccia. The material of the clasts is mainly bauxitic clay in which the directions of clasts indicate the nature of movements. The longitudinal axes of several clasts are rotated in the direction of the largest stretching (Fig. 9). The clasts were set into the texture of the rock in which they are passively rotated by simple shearing through the March mechanism (Ghos and Ramberg 1976). 
According to the relative chronology, this stress field is younger than the fourth one due to striae overprinting which could be observed in Late Miocene fissure infill in the Harsány Hill quarry. Based on this overprinting the N-S reverse striae (S4) are older than the NE-SW ones (S5). The NE-SW compression could also be examined in Pannonian rocks in the Versend quarry. This deformation phase may have operated during the Pliocene or even the Quaternary. The stress field probably changed at the end of the Late Miocene, resulting in a clockwise rotation of the maximal stress axis. The paleomagnetic data of the Pannonian sediments show different declination directions (Márton and Márton 1999). This deformation phase is of a very young age (Pliocene or younger), which is confirmed by several facts: for instance the striae overprinting in Pannonian sediments, or the morphotectonic investigations (Petrik 2010), as well as geophysical data. Determinations of recent stress fields are based on different methods but all of them indicate the NE-SW Shmax direction in the MecsekVillány zone (Bada et al. 2007). The inversion of the Pannonian Basin can be related to the northward shift and counterclockwise rotation of the Adriatic Plate (Bada et al. 2007). Based on GPS data the studied area was uplifted recently (Grenerczy and Bada 2005). The Pannonian Basin has been subjected to pressure from the direction of the Bohemian Massif, the Vrancea Zone and the Dinarides (Bada et al. 2007). The studied area is impacted by the northward rotation of the Adriatic Plate, which creates NNW-SSE compression in the Friuli Zone and eastward the shortening direction continuously changes in a clockwise direction, so that the NE-SW shortening dominates in the region of the Central Dinarides and also in the southwestern Transdanubian Hills (Bada et al. 2007). Thus the young tectonic deformation of the studied area clearly relates to the stress regime of the Central Dinarides, where the recent stress field is the same as in the studied region.

\section{Stress field No. 6 (20 striae)}

This is clearly an E-W shortening phase, which can only be observed in Lower Cretaceous limestone in the Harsány Hill quarry. This stress field consists only of reverse faults, the strike of which is $\mathrm{N}-\mathrm{S}$ (Fig. 6). The maximal stress axis is horizontal and its direction is $90^{\circ}-270^{\circ}$. Reverse faults were identified on bedding planes and ramps, not only in Mesozoic formations but also in Pannonian sediments. The stress ellipsoid of this field is located in the compressional region of the diagram (Fig. 8). Joints that are matched to this field have NW-SE and NE-SW strike, creating conjugate fractures. Similar compression was dominant in the western part of the Transdanubian Range due to of the Alps' gravitational collapse (Gerner 1991), and also in the Zala Basin (Windhoffer et al. 2001). This stress field seems to be local in the study area and it can be related to a local stress field rotation. The age of this stress field is younger than Late Miocene but it is 

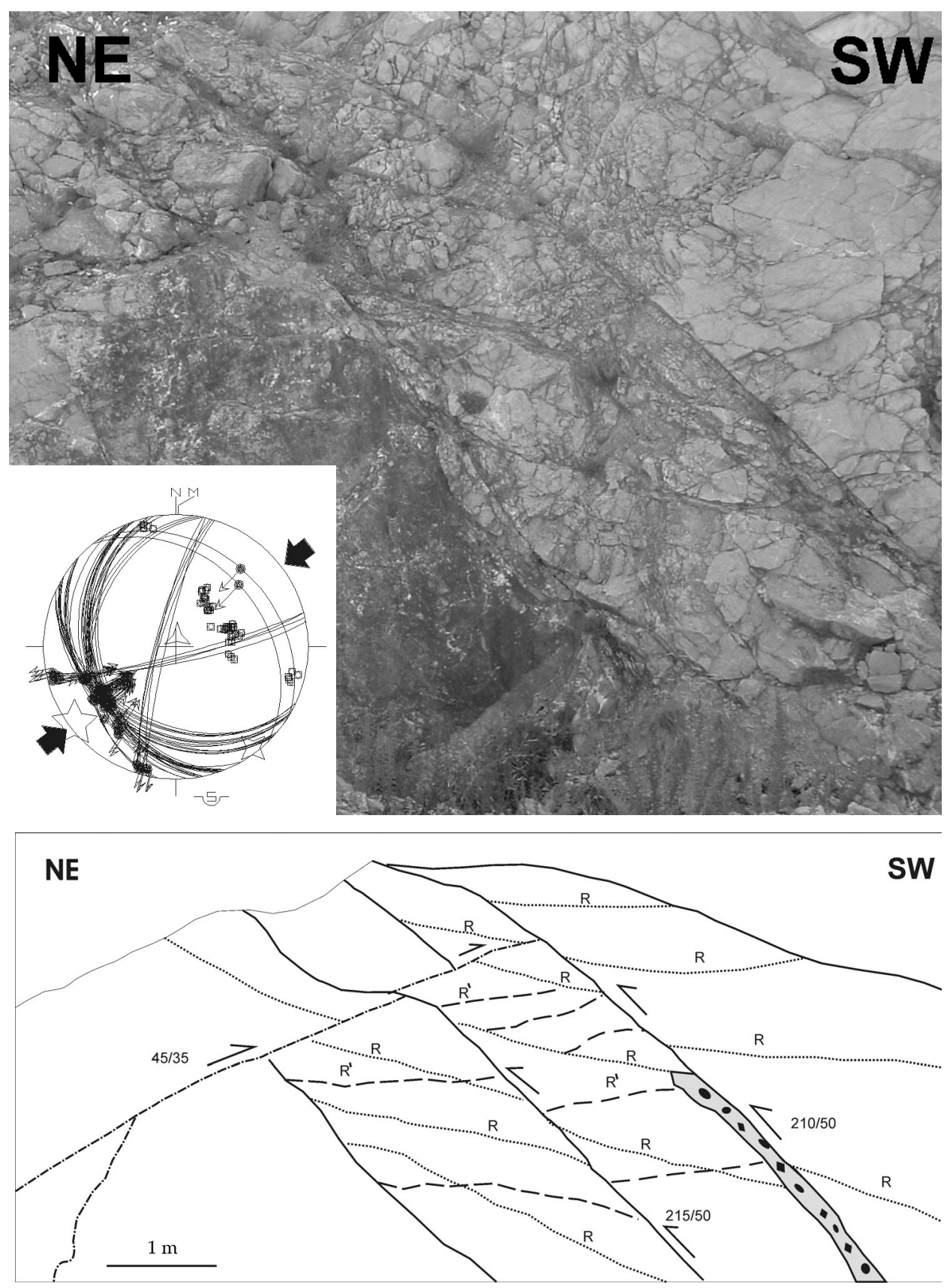

Central European Geology 53, 2010 
not possible to determine a more precise age owing to the lack of striae overprinting.

In summary, most of the stress fields (namely 4) are compressional or transpressional. The main shortening directions show clockwise rotation (S1: NW-SE, S4: N-S, S5: NE-SW, S6: E-W). Only one local stress field was assigned to the sixth main stress field observed in the Harsány Hill quarry. The S2 and S3 stress fields are tensional or transtensional. The main NE-SW extensional direction is an apparent stress field related to the clockwise block rotation. The original stress field was $\mathrm{N}-\mathrm{S}$ tension. After the block rotation the N-S real stress field was able to be developed (S2: NE-SW, S3: N-S). Based on the stress ellipsoid diagram (Fig. 8), two stress fields clearly illustrate shortening deformation (1st and 6th stress fields); two fields show transpressional style (4th and 5th stress fields), one field indicates a deformation mainly with strikE-Slip faults (2nd stress field), and finally one field clearly shows extensional deformation (3rd stress field).

\section{Discussion}

Several publications about the structural development of the Mecsek-Villány area have already appeared (Csontos and Bergerat 1988, 1993; Benkovics 1997; Csontos et al. 2002). The aim of all publications was to determine the different stress fields in the studied area based on microtectonic measurements, seismic and paleomagnetic data etc. The previous investigations extended not only into the Villány Hills but also into the Mecsek Mts, in order to determine more precise ages of different stress fields, as no Tertiary rocks are exposed in the Villány Hills.

Csontos and Bergerat (1993) observed 4 stress fields in the Mecsek-Villány Zone (Fig. 10). All stress fields could have been active in the Tertiary period. The authors assumed NW-SE compression in the Lower Miocene, which created right-lateral wrench faults of E-W strike and NNW-SSE oriented left-lateral ones in discrete zones. This stress field would have been followed by N-S compression in the Badenian and by NE-SW compression in the Early Pannonian. However the ages of two important events have remained uncertain: the NE-SW compression and the NW-SE compression. With further analysis of their data they suggested that the latter phase was younger than NE-SW compression (Csontos and Bergerat 1993), because it affected the Lower Miocene strata. They identified the young NE-SW compression as a young event in the Villány Hills

$\leftarrow$ Fig. 9

The complex Riedel system within a shear zone and conjugate reverse faults in the Harsány Hill quarry and their stereogram. (The stereographic projection was constructed on a Schmidt hemisphere with lower projection.) Legend: See Fig. 3 
which could have caused the reactivation of previous structures. On the other hand, the oldest stress field (NW-SE compression) is very likely to have been rejuvenated in the Late Pannonian, because Pannonian sediments show intense folding in that stress field.

Benkovics (1997) identified 6 stress fields in the Mecsek-Villány Zone from the Late Cretaceous (Fig. 10). The first stress field is N-S compression which was responsible for the imbrications in the Villány Hills. However, this stress field is NW-SE compression in the Mecsek Mts. based on the folding at Abaliget (Benkovics et al. 1997). According to Benkovics (1997), the NW-SE compression observed in the Mecsek Mts transformed into N-S compression in the Villány Hills in the Late Cretaceous. The next stress field he determined was NW-SE extension in consequence of E-W left lateral strikE-Slip faults in the Early Miocene which resulted in basin opening. It was followed by a second phase of $\mathrm{N}-\mathrm{S}$ compression and E-W extension in the Middle Miocene, based on synsedimentary deformation in Mecsekjános. From the beginning of the Early Pannonian NW-SE transtension with NE-SW left lateral strikE-Slips was observed in Pannonian rocks (Benkovics 1997). Structural inversion began in the Late Pannonian and resulted in reverse faults in Pannonian sediments occurring along the Mecsekalja dislocation zone. After the Late Pannonian NW-SE compression with E-W right lateral strikE-Slips was identified, based on joints and folding of Pannonian sediments. According to this author the last stress field has been active up to the present.

Csontos et al. (2002) dealt mainly with Tertiary deformation of the studied area. They determined 6 stress fields from the Paleogene to present (Fig. 10). Different data were used in their investigation, such as seismic and paleomagnetic data. They ascertained that most of the stress fields are transpressional and that the Tertiary deformation was rather complicated. After nappe formation in the Late Cretaceous, N-S compression and perhaps transpression predominated and created several small basins during the Paleogene, or even in the Early Miocene. They identified this field based on seismic sections along the Mecsekalja dislocation zone, where Carboniferous granite was thrust over poorly dated Paleogene and/or Early Miocene rocks. According to the authors, most of the Middle Miocene represents a relatively quite period from a structural point of view, while a short inversion followed in the Late Sarmatian (NE-SW transpression). This event was relayed by NE-SW directed extension-transtension, based on joints in Pannonian sediments in the Hímesháza quarry. The last stress field was NW-SE compression, which could have been active from the Late Pannonian and caused several folds in the Pannonian sediments, as well as the uplift of Görcsöny-Máriakéménd Ridge.

In comparing the data, several variations could be observed when looking at the table. It appears that the main deviations could have arisen because of the application of different methods. More methods were used in previous 
Microtectonic measurements in the Villány Hills and Görcsöny-Máriakéménd Ridge 39

\begin{tabular}{|c|c|c|c|c|}
\hline & $\begin{array}{l}\text { Csontos and } \\
\text { Bergerat (1993) }\end{array}$ & Benkovics (1997) & $\begin{array}{l}\text { Csontos et al. } \\
(2002)\end{array}$ & Petrik (2009) \\
\hline Pliocene-to date & & & & \\
\hline Late Pannonian & & & & \\
\hline Early Pannonian & & & & \\
\hline Middle-Miocene & & & & \\
\hline Early Miocene & & & & \\
\hline Paleogene & & & & \\
\hline Late Cretaceous & & & & \\
\hline
\end{tabular}

Fig. 10

Main stress directions in the study area determined by different investigators 
investigations, and those studies were extended over a greater area in order to determine the stress field more precisely.

However, in this study more numerous data were collected in more locations of the Villány Hills and the Görcsöny-Máriakéménd Ridge than in the previous studies. In addition, with the help of stria overprinting and fault crosscuttings, the relation of striae and folds and the measurements in Pannonian sediments also contributed to the determination some new stress directions, especially in the case of younger stress fields, as well as some new structures, which are presented in this paper.

\section{Conclusions}

As a result of the study six structural phases have been identified since the Late Cretaceous. Most of them show shortening, strikE-Slip deformations, and high amplitude folds; they were also the cause of other ductile elements as well as the reverse faults of the region.

In the Paleogene and Early Miocene, extension was the dominant deformation that created pull-apart basins and fissure-filling systems. The direction of the extension apparently changed from time to time because of regional clockwise block rotation.

In the Late Miocene inversion began in the studied area and these movements were mainly manifested in shortening and transpressional deformation. The reactivation of the reverse faults and the imbrication, the uplifting of the Villány Hills and the Görcsöny-Máriakéménd Ridge evolved during that time.

During inversion a clockwise stress field rotation developed N-S compression in the Pannonian Stage, NE-SW compression in the Pliocene or Quaternary, and locally $\mathrm{E}-\mathrm{W}$ compression also in the Pliocene.

The youngest stress field shows NE-SW transpression and does not correlate with the recent stress field of the Mecsek (NW-SE compression), but with the recent stress regime of the Central Dinarides (NE-SW).

The E-W compressional field can only be observed on Harsány Hill and the development of this field may be the result of a local block rotation.

A more precise age determination of the stress fields requires further investigation, especially on the Neogene rocks.

\section{Acknowledgements}

This work was supported by the National Research Fund project. I am grateful to my supervisor Prof. Dr. Géza Császár for his useful advice and help. I would like to thank Dr. László Fodor, Dr. Zoltán Balla and Ágoston Sasvári for their support, sharing their ideas and the expansion of my structural geologic knowledge. I also thank Dr. Gyula Konrád for the expansion of my theoretical and practical knowledge, Prof. Dr. Tibor Szederkényi for introducing me to the 
experience of his earlier studies. Finally, I am grateful to my classmate Deli Levente for his help in the field.

\section{References}

Angelier, J., P. Mechler 1977: Sur une méthode graphique de recherche des contraintes principales également utilisable en tectonique et en séismologie: la méthode des diédres droits. - Bull. Soc. Géol. France, 7/19, pp. 1309-1318.

Bada, G., P. Dövényi, F. Horváth, P. Szafián, G. Windhoffer 2007: Jelenkori feszültségtér a Pannonmedencében és alpi-dinári-kárpáti környezetében (Recent stress field in the Pannonian Basin and in its environment of Alps-Dinarides-Carpathians). - Földtani Közlöny, 137/3, pp. 327-359.

Benkovics, L. 1997: Etude structuale et géodynamique des Monts Buda, Mecsek et Villány (Hongrie). - These, L'Université des Sciences et Technologies de Lille, pp. 203.

Benkovics, L., J-L. Mansy, L. Csontos, F. Bergerat 1997: Folding in the roadcut of Abaliget (Mecsek Mts). - Acta Geologica Hungarica, 40/4, pp. 425-440.

Blehau, M., G. Mantea, S. Bordea, S. Panin, M. Stefanescu, K. Sikic, J. Haas, S. Kovács, Cs. Péró, A. Bérczi-Makk, Gy. Konrád, E. Nagy, E. Rálisch-Felgenhauer, Á. Török 1996: Triassic facies types, evolution and paleogeographic relations of the Tisza Mega-unit. - Acta Geologica Hungarica, 37/3-4, pp. 187-234.

Császár, G. 1992: Urgonian facies of the Tisza unit. - Acta Geologica Hungarica, 35/3, pp. 263-285.

Császár, G. 2002: Urgon formations in Hungary with special reference to the Eastern Alps, the Western Carpathians and the Apuseni Mountains. - Geologica Hungarica, ser, Geol. 25, 209 p.

Csontos, L. 1998: Szerkezeti földtan (Structural geology). - ELTE Eötvös Kiadó, Budapest, pp. 10-50, 60-109.

Csontos, L., F. Bergerat 1988: Brittle Tectonics and Paleo-stress field in the Mecsek and Villány Mts (Hungary): Correlation with the opening mechanism of the Pannonian Basin. - Acta Geologica Hungarica, 31/1-2, pp. 81-100.

Csontos, L., F. Bergerat 1993: Reevaluation of the Neogene brittle tectonics of the Mecsek-Villány area (SW Hungary). - Ann. Univ. Sci. Bp. Rolando Eötvös Nomin., Sect. Geol, 29, pp. 3-12.

Csontos, L., E. Márton, G. Wórum, L. Benkovics 2002: Geodynamics of SW-Pannonian inselbergs (Mecsek and Villány Mts SW Hungary): Inferences from a complex structural analysis. - EGU Stephan Mueller Special Publication Series, 3, pp. 227-245.

Delvaux, D., B. Sperner 2003: Stress tensor inversion from fault kinematic indicators and focal mechanism data: the TENSOR program. - In: Nieuwland, D. (Ed.): New Insights into Structural Interpretation and Modelling - Geological Society, London. Special Publications 212, pp. $75-100$.

Dezsô, J., B. Raucsik, I. Viczián 2007: Villányi-hegységi karsztos hasadékkitöltések szemcseösszetételi és ásványtani vizsgálata (Granulometric and mineralogical analysis of karstic fissure filling sediments in Villány Mts, S Hungary). - Acta GGM Debrecina, Geology, Geomorphology, Physical Geography Ser, 2, (in prep.)

Fodor, L., L. Csontos, G. Bada, I. Györfy, L. Benkovics 1999: Tertiary tectonic evolution of the Pannonian Basin system and neighbouring orogens: a new synthesis of paleostress data. Geological Society, London. Special publication 156, pp. 295-334.

Fülöp, J. 1994: Magyarország geológiája. Paleozoikum II (The geology of Hungary). - Akadémiai Kiadó, Budapest, 447 p.

Gerner, P. 1991: Recens kôzetfeszültség a Dunántúlon (Recent rock stress field in the Transdanubia). - Földtani Közlöny, 122, pp. 89-105.

Ghos, S.K., H. Ramberg 1976: Reorientation of inclusions by combination of pure shear and simple shear. - Tectonophysics, 34, pp. 1-70.

Grenerczy, Gy., G. Bada 2005: GPS baseline length changes and their tectonic interpretation in the Pannonian Basin. - Geophysical Research Abstracts, 7, no. 04808. 
Györfi, I., L. Csontos 1994: Structural evolutions of SE Hungary and Neogene basins of the Apuseni Mountains (Romania). - Rom. J. Tecton. Reg. Geol., 75 (Suppl. 1), pp. 19-20.

Horváth, F. 1993: Towards a mechanical model for the formation of the Pannonian basin. Tectonophysics, 226, pp. 333-357.

Maros, Gy. 1990: A Villányi-hegység, Tenkes-hegy Vizig-kőfejtőjének szerkezetföldtani viszonyai (The structural geological conditions of the Vizig quarry in Villány Hills). - Országos Földtani és Geofizikai Adattár, T. 16870

Márton, E., P. Márton 1999: Tectonic aspects of a paleomagnetic study on the Neogene of the Mecsek Mountains. - Geophysical Transactions, 42/3-4, pp. 55-98, 159-180.

Nagy, E., I. Nagy 1976: A Villányi-hegység triász képződményei (Triassic formations of the Villány Hills). - Geologica Hungarica, Ser. Geol., 17, pp. 113-227.

Nédli, Zs. 2004: A Villányi-hegység bázisos teléreinek petrográfiája, geokémiája és petrogenetikája (Petrography, geochemistry and petrogenesis of the basic subvolcanic rocks in the Villány Mts). - PhD thesis, Szeged, pp. 25-72.

Némedi Varga, Z. 1983: A Mecsek hegység szerkezetalakulása az alpi hegységképződési ciklusban (The structural development of the Mecsek Mts. in the cycle of the Alps orogenesis). - MÁFI Évi Jelentés, 1981, pp. 467-484.

Pap, S. 1990: Felpikkelyezett rétegsorok a Közép-Tiszántúlon (Imbricated sequences in the MiddleTrans-Tisian area). - MÁFI alkalmi kiadványa (Spec. Publ. Hung. Geol. Surv.) Budapest, 36 p.

Petrik, A. 2009: A villányi-hegységi mezozoos képződmények mikrotektonikai méréseinek értelmezése (Interpretation of the results of microtectonic measurements performed with respect to mesozoic formations of the Villány Hills). - Földtani Közlöny, 139/3, pp. 1-20.

Petrik, A. 2010: A Villányi-hegység és térségének morfometriai és morfotektonikai vizsgálata digitális terepmodell alapján (The morphotectonic investigation of the Villány Hills based on digital elevation model). - PTE-TTK, Diploma Thesis $61 \mathrm{p}$.

Rakusz, Gy., L. Strausz 1953: A Villányi-hegység földtana (The geology of Villány Hills). - MÁFI Évkönyve, 1953. 41/2, pp. 1-43.

Tari, G., P. Dövényi, I. Dunkl, F. Horváth, L. Lenkey, M. Stefanescu, P. Szafián, T. Tóth 1999: Lithospheric structure of the Pannonian Basin derived from seismic, gravity and geothermal data. - In: Durand, B., L. Jolivet, F. Horváth, M. Séranne (Eds): The Mediterranean Basins: Tertiary extension within the Alpine orogen. - Geological Society, London, Spec. Publ., 156, pp. 215-250.

Török, Á. 1998: A Mecsek-Villányi egység triász képződményeinek rétegtana (The stratigraphy of the Triassic formations in the Mecsek-Villány Zones). - In: Bérczi, I., Á. Jámbor (Eds): Magyarország geológiai képződményeinek rétegtana. (The stratigraphy of Hungary's geological formations). - MOL Rt. és a MÁFI kiadványa, Budapest, pp. 253-279.

Twiss, R.J., E.M. Moores 1992: Structural Geology. - Freeman Co. New York. 532 p.

Vadász, E. 1935: A Mecsekhegység. Magyar tájak földtani leírása (The Mecsek Mountains. The geological description of the Hungarian landscapes). - Magyar Királyi Földtani Intézet, Budapest, 148 p.

Windhoffer, G., G. Bada, P. Dövényi, F. Horváth 2001: Új kőzetfeszültség meghatározások Magyarországon lyukfaldeformációs mérések alapján (New rock stress determination in Hungary based on sidewall-deformation measurements). - Földtani Közlöny, 131/3-4, pp. 541-560.

Wórum, G. 1999: A Mecsek-Villányi térség szerkezete és fejlődéstörténeti eseményei szeizmikus szelvények alapján (The structural development and events of the Mecsek Mts and the Villány Hills, based on seismic sections). - Diploma thesis, ELTE Department of Geophysics, pp. 9-60, $70-140$. 